\title{
Influence of Levels of Awareness, Willingness to Pay, and Incentives on Solid Waste Management Practices by Commercial Enterprises in Kakamega Town
}

\author{
Robert Mbatsi Kuya, Boniface Oluoch Oindo, and Albert Elim Long’ora
}

\section{ABSTRACT}

Globally, there has been an increase in population that has led to increased urbanization and change in consumption patterns. This has led to an increase in solid waste generation. Commercial enterprises have also increased exponentially, which has resulted in an increase in solid waste generation worldwide and Kakamega town. This study sought to analyse the influence of the levels of awareness, willingness to pay, and incentives on solid waste collection, transportation, and disposal by commercial enterprises in Kakamega town. A cross-sectional research design was employed. A minimum sample size of 300 commercial enterprises was drawn from a study population of 1,372 commercial enterprises using Taro Yamen formula. Simple random sampling was used to identify the commercial enterprises within the study area. Purposive sampling was used to identify key informants such as the Town Manager and the Director of the environment who were interviewed. Primary data were collected through structured questionnaires administered to the commercial enterprises, interview schedules for key informants, focused group discussions, and photography. Quantitative data were analysed using descriptive statistics: percentages, frequencies, means, graphs, and pier chats. Qualitative data were analysed thematically along with the research objectives and presented in narrative form. Spearman's rank correlation was used to determine the relationship between the dependent variables as explained by the independent variables in the study; Levels of awareness, willingness to pay, incentives. The analysed findings were presented inform of tables, figures, and plates. Results shows that the awareness levels on solid waste transportation and disposal were extremely high at $r=0.882$, compared to the collection at $r=0.375$. Thus, the frequency of solid waste collection could not influence the frequency of solid waste transportation and disposal. Provision of incentives such as reduced charges, provision of defined transfer point, provision of waste holding bins were extremely high thus influencing the solid waste management practices by the commercial enterprises at $r=0.830$. Most of the commercial enterprises were willing to pay for solid waste management to the municipal council at $64 \%$. Using the results, the County Government of Kakamega can incorporate all the waste generators in the solid waste management hierarchy thus improving on solid waste management practices and converting the waste into cash.

Keywords: Commercial enterprises, Solid waste management, Urban environment, Waste fees.
Published Online: January 20, 2022

ISSN: 2684-446X

DOI :10.24018/ejgeo.2022.3.1.236

\section{R. M. Kuya*}

Maseno University, Maseno, Kisumu County, Kenya.

(e-mail: kuya200@gmail.com)

B. O. Oindo

Maseno University, Maseno, Kisumu

County, Kenya.

Department of Environmental Sciences,

School of Agriculture, Food Security and Environmental Sciences, Kenya.

(e-mail: bonifaceoindo@gmail.com) A. E. Long'ora

Maseno University, Maseno, Kisumu County, Kenya.

Department of Environmental Sciences, School of Agriculture, Food Security and Environmental Sciences, Kenya. (e-mail: longoralbert ${ }^{@}$ gmail.com)

* Corresponding Author

\section{INTRODUCTION}

In 2018, global solid waste generation stood at 11.2 billion tonnes generated every year [1]; of which only about $37 \%$ was properly managed. It is argued that commercial enterprises globally have sufficient knowledge on the implication of unmanaged or poorly managed solid wastes but still violate solid waste management practices [2]. Moreover, [2], it was added that low income among the commercial enterprises in the global south contributes $63 \%$ of poor solid wastes managed globally. It was reported that in Europe, the solid waste collection covers $98 \%$, whereas member countries minimize direct disposal and embrace making sustainable products from wastes [3]. These studies agree that despite developed countries improving in the solid waste collection (98\%), there is still an increase in the solid waste generation which has escalated the cost of solid waste management.

In Africa, the municipal councils are known for solid waste management practices [4]. Thus, commercial enterprises do not do much to help the situation [5], hence resulting in ineffective collection methods [6]. Commercial enterprises are willing to pay for solid waste management practices, but financial constraints limit the participation of some commercial enterprises [7], [8]. Despite the commercial enterprise high levels of awareness in solid waste management, they are not involved, which exacerbates poor solid waste management practices [9]. These studies 
appreciate the willingness to pay for solid waste management practices by the community and households, however, little focus was given to the commercial enterprises.

In Kenya, it was noted that poor solid waste management practice was contributed to scanty public awareness [10]. Moreover, it was agreed that income and education among waste generators were the essential determinants of solid waste generation and its management practices [11], [12]. While it was concluded that solid waste management challenges were contributed to by poor levels of awareness among key players and inadequate funding for waste management [13]. These studies have helped us understand that lack of awareness and income highly influenced solid waste management practices in the municipality but not in commercial enterprises.

In Kakamega town [14], it was noted that the exacerbated solid waste management challenges are caused by a lack of commercial enterprise participation in solid waste management practices [15]. It was added that there are inadequacies in awareness creation and financial constraints among commercial enterprises. Furthermore, the lack of awareness and inadequate financing among the municipalities have negatively impacted solid waste management practices [16]. Besides, it was revealed that most commercial enterprises seldom participate in solid waste management practices [17]. It is known from these studies that low levels of awareness and financial constraints negatively affected solid waste management in general; however, they were not specific to commercial enterprises.

\section{PROBLEM STATEMENT}

Globally, the developed countries generate a lot of waste; however, they have excellently implemented their solid waste management practices. In the global south, commercial enterprises are not directly involved in solid waste management practices. Thus, there is limited literature capturing their level of awareness. In Kenya, lack of awareness and income highly influence solid waste management practices in the municipalities. Besides, only a few studies have looked at the influence of commercial enterprises in solid waste management practices. In Kakamega municipality, the previous studies showed that there was a low level of awareness and financial constraints among its urban population. This had a negative effect on solid waste management practices by the municipality. However, these previous studies were not specific to commercial enterprises in Kakamega town. Moreover, these studies concluded that the commercial enterprises had a perceived notion that Kakamega municipality has the sole responsibility on solid waste management practices. From these backdrops, there was a need to investigate how the level of awareness, willingness to pay and incentives influence commercial enterprise solid waste management practices. This study is important as it will help Kakamega municipality to come up with practical solutions that will address the inadequacy in awareness levels, funding and incentives. The purpose of this study was therefore to analyse the levels of awareness, willingness to pay, and incentives influencing solid waste collection, transportation and disposal by commercial enterprises in Kakamega Town, Kenya.

\section{CONCEPTUAL FRAMEWORK}

This paper hypothesis that level of awareness, willingness to pay and incentives (perception, behaviour, income level, education level and motivation - return fee) is a determinant of solid waste management practices by commercial enterprises.

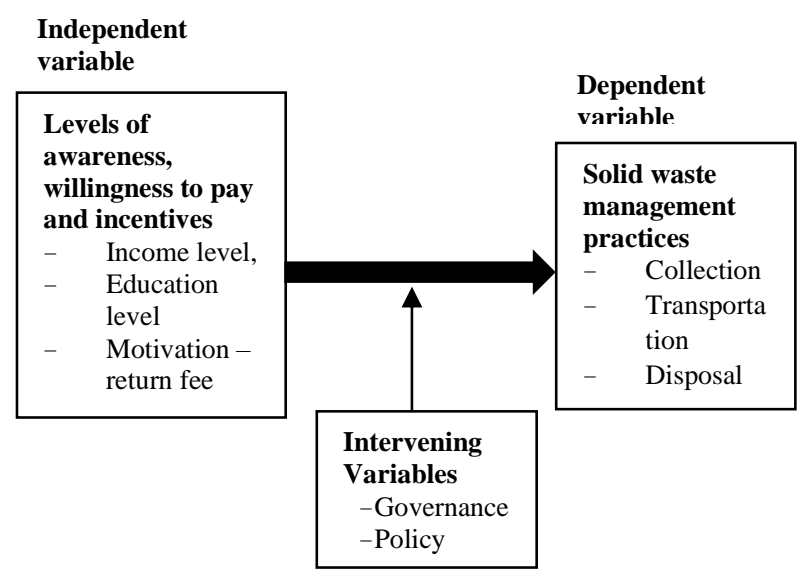

Fig. 1. Conceptual framework.

\section{MATERIALS AND METHODS}

This study was conducted in Kakamega town central business district. Kakamega town generates about 1,632 tonnes of waste per day [18]. Thus, there is increased solid waste generation by the commercial enterprises in Kakamega town which are left littering and a nuisance to the environment. The cross-sectional research design was used to assess solid waste management practices by the commercial enterprise in Kakamega town. In 2019 the total population was $1,867,579$ inhabitants with an urban population of 188,212 within an area of $155.2 \mathrm{~km}^{2}$ [19]. Thus, Kakamega Town central business district (CBD) has about 1,372 commercial enterprises, which formed the target population and were sampled using simple random. The key informants of this study were made up of the municipal manager and the Kakamega County Director of Environment for the National Environment Management Authority (NEMA) and were sampled purposively. The sample size was calculated using the Taro Yamane formula for a study population of less than 10,000 .

Formula target population less than 10,000, the sample size was determined as follows (Commercial enterprises $=1,372$ )

$$
\begin{aligned}
& n_{o}=\frac{n}{1+\frac{(n-1)}{N}} \\
& n_{o}=\frac{384}{1+\frac{(384-1)}{1372}}=\mathbf{3 0 0} \text { Commercial Enterprises }
\end{aligned}
$$

Data collection were done using questionnaires, interviews guide, focus group discussion and photography. Only primary data was given priority in this study as it provided the most important and necessary data required to answer questions. Quantitative data were coded and analysed using Statistical Package for the Social Sciences (SPSS) version 25 at 0.05 significance level. Data were presented in tables and figures. Qualitative data were coded and reported in verbatim that 
triangulated with the quantitative data. Reliability was achieved through a pre-test of tools which scored 0.785 . While validity was achieved through cross-checking with supervisors. Finally, the researcher obtained permission from Maseno University Ethics Review Committee and the National Commission for Science, Technology, and Innovation (NACOSTI) to carry out the study to guard against ethical issues. Confidentiality of information and anonymity of data recording was assured using written consent on every questionnaire.

\section{RESULTS}

\section{A. Demographic Characterization of the Prison Officers}

The researcher sought to establish the level of awareness among commercial enterprises in Kakamega town. The findings are presented in Table I on the collection, transportation and safe disposal of solid wastes.

TABLE I: LEVEL OF AWARENESS AMONG COMMERCIAL ENTERPRISES

\begin{tabular}{|c|c|c|c|c|c|c|}
\hline $\begin{array}{c}\text { levels of } \\
\text { Awareness }\end{array}$ & $\begin{array}{c}\text { Not at } \\
\text { all }\end{array}$ & $\begin{array}{l}\text { Slightly } \\
\text { aware }\end{array}$ & & $\begin{array}{l}\text { oderately } \\
\text { aware }\end{array}$ & $\begin{array}{c}\text { Very } \\
\text { aware }\end{array}$ & $\begin{array}{c}\text { Extremely } \\
\text { aware }\end{array}$ \\
\hline Colle & $033 \%$ & $206.7 \%$ & 68 & $22.7 \%$ & $108360 \%$ & $94 \quad 3$ \\
\hline Trans & & 3712 & 28 & & & 114 \\
\hline Safe disposal & $5016.8 \%$ & $4314.4 \%$ & 42 & $14.1 \%$ & $5117.1 \%$ & $11237.6 \%$ \\
\hline
\end{tabular}

According to the findings in Table I, the awareness levels on solid waste management practices by the respondents were very aware and extremely aware at $(67.3 \%)$ on the collection, transportation to transfer point/disposal site (59.4\%), and safe disposal $(54.7 \%)$.

This finding was corroborated by a focused group discussion that stated that:

...each individual cleans his/her business premises and leaves the waste for the municipal council to transfer to the final disposal site. Also, the vehicle used in transportation is open up thus do litter on the way to the disposal sites. We believe the little money we pay to the municipality should be enough for waste management within the CBD.

Whereas the key informants added by stating that:

... we have engaged commercial enterprises in solid waste management practices. Though not explicitly, but we have tried to create awareness.

... I know, as an authority on environmental matters, we have the responsibility of educating the commercial enterprises especially through environmental audits on a commercial enterprise. There are commercial enterprises that are aware of solid waste management practices from the recommendation made on the environmental audit action plan.

A spearman's rank correlation coefficient was computed to ascertain the relationship between waste collection and transportation and safe disposal. The results were presented in Table II.
TABLE II: CORRELATIONS FOR WASTE COLLECTION, TRANSPORTATION, AND SAFE DISPOSAL

\begin{tabular}{|c|c|c|c|c|c|}
\hline & & & Collection & ansportation & $\begin{array}{c}\text { Safe } \\
\text { disposal }\end{array}$ \\
\hline \multirow{9}{*}{$\begin{array}{l}\text { Spearman's } \\
\text { rho }\end{array}$} & \multirow{3}{*}{ Collection } & $\begin{array}{l}\text { Correlation } \\
\text { Coefficient }\end{array}$ & 1.000 & $0.375^{* *}$ & $0.385^{* *}$ \\
\hline & & Sig. (2-tailed) & & 0.000 & 0.000 \\
\hline & & $\mathrm{N}$ & 300 & 298 & 298 \\
\hline & \multirow{3}{*}{ Transportation } & $\begin{array}{l}\text { Correlation } \\
\text { Coefficient }\end{array}$ & $0.375^{* *}$ & 1.000 & $0.882^{* *}$ \\
\hline & & Sig. (2-tailed) & 0.000 & & 0.000 \\
\hline & & $\mathrm{N}$ & 298 & 298 & 298 \\
\hline & \multirow{3}{*}{ Safe disposal } & $\begin{array}{l}\text { Correlation } \\
\text { Coefficient }\end{array}$ & $0.385^{* *}$ & $0.882^{* *}$ & 1.000 \\
\hline & & Sig. (2-tailed) & 0.000 & 0.000 & \\
\hline & & $\mathrm{N}$ & 298 & 298 & 298 \\
\hline
\end{tabular}

**. Correlation is significant at the 0.01 level (2-tailed).

The results from Spearman's rank correlation coefficient in Table II, show that the awareness level of collection $(\mathrm{r}=0.375)$ which is close to zero can weakly predict the awareness level on transportation and disposal of solid wastes. However, it could be seen that transportation $(\mathrm{r}=0.882)$ and disposal $(\mathrm{r}=0.882)$ which is close to one means that extremely aware tend to occur together. Thus, if the respondent were participating in solid waste transportation, then they were extremely aware of the disposal site; while awareness in the collection does not influence transportation and disposal. These findings were triangulated by focused group discussion stating that:

...the respondents were aware of their waste transportation thus final disposal sites e.g. most of the waste is disposed at Rostaman dumpsite, little is taken back to Nairobi for recycling. For those who collected dumped it at the transfer station.

B. Willingness to Pay

The willingness to pay for commercial solid waste management was examined in Kakamega town's central business district. The willingness to pay, payment for collection and payment for transportation. Table III presents the findings.

TABLE III: WILLINGNESS TO PAY

\begin{tabular}{ccc}
\multicolumn{3}{c}{ TABLE III: WILLINGNESS TO PAY } \\
\hline Willingness to pay & Frequency $(\mathrm{n})$ & Per cent $(\%)$ \\
\hline Willing to pay for & & \\
Yes & 192 & 64 \\
No & 108 & 36 \\
Payment for Collection & & \\
Daily & 203 & 67.6 \\
Weekly & 97 & 32.4 \\
Payment for Transportation & & \\
Daily & 114 & 38.1 \\
None & 186 & 61.9 \\
\hline \hline
\end{tabular}

According to the commercial enterprises' survey (Table III), about two-thirds (192) of the respondents were willing to pay for solid waste management. It was established that $67.6 \%$ (203) of the commercial enterprises paid for transportation daily while only $32.4 \%$ (97) paid for collection on a weekly basis.

Key informant 1 stated that:

... Revenue collection is done annually to cater for the County Government of Kakamega to run the county effectively. Focus on solid waste 
management has not been given priority as such as compared to other sectors. And this has led to increased challenges which again has made commercial enterprises reluctant to pay for solid waste management privately.

A paired sample t-test was performed thereafter to establish whether there was a significant difference between solid waste collection and solid waste transportation to the transfer point/disposal sites. The results are presented in Table IV and Table V.

TABLE IV: PAIRED SAMPLES STATISTICS - COLLECTION AND

\begin{tabular}{|c|c|c|c|c|}
\hline & Mean & $\mathrm{N}$ & Std. Deviation & $\begin{array}{c}\text { Std. Error } \\
\text { Mean }\end{array}$ \\
\hline Collection Amount & 92.00 & 300 & 27.982 & 1.616 \\
\hline${ }^{2}$ Transportation Amount & 71.31 & 300 & 22.102 & 1.276 \\
\hline
\end{tabular}

According to the paired t-test, it was established that there was a significant difference between collection $(\mathrm{M}=92.0$, $\mathrm{SD}=27.98)$ and transportation $(\mathrm{M}=71.31, \mathrm{SD}=22.1)$ amounts paid for the services of solid waste management; $t$ (299) $=10.44, p<0.001)$. Moreover, the focused group discussion findings added that:
... We do not see any great difference between the amount paid for collection and transportation from the commercial enterprises. They are averagely the same.

\section{Incentives}

The researcher investigated whether incentives were extended to the commercial enterprise to motivate them in solid waste management practices. Waste storage, adequate bins, adequate collection points, frequency of collection of wastes, the amount charged for collection and transportation, availability of solid waste management equipment, proximity to both transfer points and disposal sites were investigated. Table VI illustrates the findings.

From the findings in Table VI, accessibility to transfer points/ dumpsites was influenced by the availability of equipment $(74.7 \%)$ and their proximities $(70 \%)$ to commercial enterprises.

The Spearman's Rank correlation was computed to establish whether there was a significant relationship between the waste storage and adequate bins, adequate collection points, frequent collection, low charges, availability of equipment, proximity to transfer point, proximity to the disposal site. Table VII illustrates the finding.

TABLE V: PAIRED SAMPLES TEST

\begin{tabular}{|c|c|c|c|c|c|c|c|c|c|}
\hline & & \multicolumn{5}{|c|}{ Paired Differences } & \multirow{3}{*}{$\mathrm{t}$} & \multirow{3}{*}{ Df } & \multirow{3}{*}{ Sig. (2-tailed) } \\
\hline & & \multirow[t]{2}{*}{ Mean } & \multirow{2}{*}{$\begin{array}{c}\text { Std. } \\
\text { Deviation }\end{array}$} & \multirow{2}{*}{$\begin{array}{l}\text { Std. Error } \\
\text { Mean }\end{array}$} & \multicolumn{2}{|c|}{$\begin{array}{l}\text { 95\% Confidence Interval of the } \\
\text { Difference }\end{array}$} & & & \\
\hline & & & & & Lower & Upper & & & \\
\hline $\begin{array}{c}\text { Pair } \\
1\end{array}$ & $\begin{array}{c}\text { Collection Amount - } \\
\text { Transportation } \\
\text { Amount }\end{array}$ & 20.683 & 34.313 & 1.981 & 16.785 & 24.582 & 10.441 & 299 & 0.000 \\
\hline
\end{tabular}

TABLE VI: INCENTIVES FOR SOLID WASTE MANAGEMENT PRACTICES

\begin{tabular}{|c|c|c|c|c|c|c|c|c|c|c|}
\hline \multirow{2}{*}{$\frac{\text { Level of Importance }}{\text { Waste storage }}$} & \multicolumn{2}{|c|}{ Not at all } & \multicolumn{2}{|c|}{ Slightly } & \multicolumn{2}{|c|}{ Moderately } & \multicolumn{2}{|c|}{ Very } & \multicolumn{2}{|c|}{ Extremely } \\
\hline & 12 & $4.0 \%$ & 0 & $0.0 \%$ & 27 & $9.0 \%$ & 123 & $41.0 \%$ & 138 & $46.0 \%$ \\
\hline Provision of adequate storage bins & 12 & $4.0 \%$ & 6 & $2.0 \%$ & 63 & $21.0 \%$ & 127 & $42.3 \%$ & 92 & $30.7 \%$ \\
\hline Provision of adeq & 0 & $0.0 \%$ & 42 & $14.3 \%$ & 39 & $13.3 \%$ & 126 & $42.9 \%$ & 87 & $29.6 \%$ \\
\hline Frequent collection of waste & 6 & $2.0 \%$ & 12 & $4.0 \%$ & 36 & $12.0 \%$ & 118 & $39.3 \%$ & 128 & $42.7 \%$ \\
\hline Low charges for waste collection and transportation & 12 & $4.1 \%$ & 22 & $7.5 \%$ & 23 & $7.8 \%$ & 55 & $18.7 \%$ & 182 & $61.9 \%$ \\
\hline Availability of equipment & 6 & $2.0 \%$ & 6 & $2.0 \%$ & 34 & $11.3 \%$ & 143 & $47.7 \%$ & 111 & $37.0 \%$ \\
\hline Proximity to & 24 & $8.2 \%$ & 18 & $6.1 \%$ & 46 & $15.6 \%$ & 83 & $28.2 \%$ & 123 & $41.8 \%$ \\
\hline Proximity to the disposal site & 59 & $20.1 \%$ & 35 & $11.9 \%$ & 59 & $20.1 \%$ & 69 & $23.5 \%$ & 72 & $24.5 \%$ \\
\hline
\end{tabular}

\begin{tabular}{|c|c|c|c|c|c|c|c|c|c|c|}
\hline & & & $\mathrm{A}$ & $\mathrm{B}$ & $\mathrm{C}$ & $\mathrm{D}$ & $\mathrm{E}$ & $\mathrm{F}$ & $\mathrm{G}$ & $\mathrm{H}$ \\
\hline \multirow{22}{*}{ Spearman's rho } & \multirow{3}{*}{ A } & Correlation Coefficient & 1.000 & $0.426^{* *}$ & $0.480^{* *}$ & $0.259^{* *}$ & 0.003 & $0.246^{* *}$ & $0.294^{* *}$ & $0.295^{* *}$ \\
\hline & & Sig. (2-tailed) & & 0.000 & 0.000 & 0.000 & 0.963 & 0.000 & 0.000 & 0.000 \\
\hline & & $\mathrm{N}$ & 300 & 300 & 294 & 300 & 294 & 300 & 294 & 294 \\
\hline & \multirow{3}{*}{$\mathrm{B}$} & Correlation Coefficient & $0.426^{* *}$ & 1.000 & $0.387^{* *}$ & $0.569^{* *}$ & $0.190^{* *}$ & $0.443^{* *}$ & $0.395^{* *}$ & $0.284^{* *}$ \\
\hline & & Sig. (2-tailed) & 0.000 & & 0.000 & 0.000 & 0.001 & 0.000 & 0.000 & 0.000 \\
\hline & & $\mathrm{N}$ & 300 & 300 & 294 & 300 & 294 & 300 & 294 & 294 \\
\hline & \multirow{2}{*}{$\mathrm{C}$} & Correlation Coefficient & $0.480^{* * *}$ & $0.387^{* *}$ & 1.000 & $0.400^{* *}$ & $0.182^{* *}$ & $0.528^{* *}$ & $0.556^{* *}$ & $0.549^{* *}$ \\
\hline & & $\mathrm{N}$ & 294 & 294 & 294 & 294 & 294 & 294 & 294 & 294 \\
\hline & \multirow{3}{*}{$\mathrm{D}$} & Correlation Coefficient & $0.259^{* *}$ & $0.569^{* *}$ & $0.400^{* *}$ & 1.000 & $0.248^{* *}$ & $0.533^{* *}$ & $0.349^{* *}$ & $0.287^{* *}$ \\
\hline & & Sig. (2-tailed) & 0.000 & 0.000 & 0.000 & & 0.000 & 0.000 & 0.000 & 0.000 \\
\hline & & $\mathrm{N}$ & 300 & 300 & 294 & 300 & 294 & 300 & 294 & 294 \\
\hline & \multirow{3}{*}{$\mathrm{E}$} & Correlation Coefficient & 0.003 & $0.190^{* *}$ & $0.182^{* *}$ & $0.248^{* *}$ & 1.000 & $0.387^{* *}$ & $0.269^{* *}$ & $0.336^{* *}$ \\
\hline & & Sig. (2-tailed) & 0.963 & 0.001 & 0.002 & 0.000 & & 0.000 & 0.000 & 0.000 \\
\hline & & $\mathrm{N}$ & 294 & 294 & 294 & 294 & 294 & 294 & 294 & 294 \\
\hline & \multirow[b]{2}{*}{$\mathrm{F}$} & Correlation Coefficient & $0.246^{* *}$ & $0.443^{* *}$ & $0.528^{* *}$ & $0.533^{* *}$ & $0.387^{* *}$ & 1.000 & $0.586^{* *}$ & $0.474^{* *}$ \\
\hline & & Sig. (2-tailed) & 0.000 & 0.000 & 0.000 & 0.000 & 0.000 & & 0.000 & 0.000 \\
\hline & \multirow{3}{*}{ G } & Correlation Coefficient & $0.294^{* * *}$ & $0.395^{* *}$ & $0.556^{* *}$ & $0.349^{* *}$ & $0.269^{* *}$ & $0.586^{* *}$ & 1.000 & $0.720^{* *}$ \\
\hline & & Sig. (2-tailed) & 0.000 & 0.000 & 0.000 & 0.000 & 0.000 & 0.000 & & 0.000 \\
\hline & & $\mathrm{N}$ & 294 & 294 & 294 & 294 & 294 & 294 & 294 & 294 \\
\hline & \multirow{3}{*}{$\mathrm{H}$} & Correlation Coefficient & $0.295^{* *}$ & $0.284^{* *}$ & $0.549^{* *}$ & $0.287^{* *}$ & $0.336^{* *}$ & $0.474^{* *}$ & $0.720^{* *}$ & 1.000 \\
\hline & & Sig. (2-tailed) & 0.000 & 0.000 & 0.000 & 0.000 & 0.000 & 0.000 & 0.000 & \\
\hline & & $\mathrm{N}$ & 294 & 294 & 294 & 294 & 294 & 294 & 294 & 294 \\
\hline
\end{tabular}

**. Correlation is significant at the 0.01 level (2-tailed).

KEY: A. Waste storage; B. The provision of an adequate number of storage bins; C. Provision of adequate number of collection points; D. Frequent collection of waste; E. Low charges for waste collection and transportation, F. Availability of equipment; G. Proximity to the transfer point; H. Proximity to the disposal site. 
It was established that the provision of incentives on waste storage moderately predicted the provision of adequate bins and the provision of adequate collection points. The medium positive correlation coefficients $(r=0.426)$ and $(r=0.480)$ show that the provision of adequate bins and collection points was an important incentive that tend to occur together. The provision of adequate waste storage bins is a very important incentive that moderately predicts the frequency of collection $(r=0.569)$ and availability of equipment $(r=0.443)$. Provision of collection points was a very important incentive that moderately predicts frequent collection of waste $(r=0.400)$, availability of equipment $(\mathrm{r}=0.528)$, proximity to the transfer point $(\mathrm{r}=0.556)$, and proximity to the disposal site $(\mathrm{r}=0.549)$. Frequency of collection is a very important incentive that moderately predicts the availability of equipment $(r=0.533)$ for solid waste management practices. Availability of equipment was an important incentive that moderately predicts the proximity to the transfer points $(r=0.580)$ and proximity to the disposal sites $(r=0.474)$. Finally, the proximity to the transfer points is a very important and extremely important incentive that strongly predicts the proximity to the disposal sites $(\mathrm{r}=0.720)$. this means the two events tend to occur together.

The level importance of charges imposed on solid waste collection and transportation were studied as shown in Fig 1.

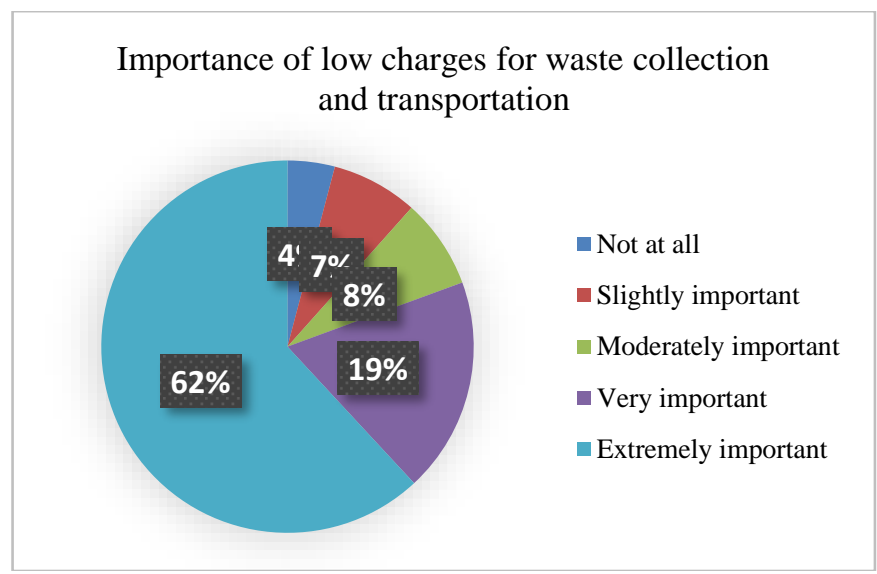

Fig 1: Importance of low charges for waste collection and transportation.

According to the results, $62 \%$ observed that the low charges imposed on solid waste management were extremely important in promoting commercial enterprises' participation in solid waste management practices.

\section{DISCUSSION}

\section{A. Level of Awareness}

Commercial enterprises survey showed that the participants were aware of solid waste management practices. The findings are supported by [20], which found that it was highly likely for the commercial enterprises to be aware of solid waste management collection practices but violate the practice. These findings were contrary to previous studies [5], [21]-[23] that most commercial enterprises were not aware of solid waste management practices hence leading to poor solid waste management culture. According to [2], it was a wellknown fact that urbanites globally were sufficiently aware of the implication of unmanaged or poorly managed solid waste in the environment. Solid waste reuse is one of the global mantras to securing the global population against the burgeoning solid wastes hotspots in urban and peri-urban centres. Therefore, why are solid wastes becoming a problem in the global South? The World Bank in 2018 made a report that, of 2.01 billion tonnes of municipal solid waste generated annually, 33 per cent were not managed properly [1]. Knowledge of solid waste management is prime in advancing the safe management of solid wastes, especially at the source. Human behaviour and the urban cultural norms have exacerbated mismanagement of solid wastes in urban centres of Africa as also reported by [24]. This is the untapped potential by most commercial enterprises in the global south; hence increased availability of solid wastes in Kakamega town CBDs. Why is solid waste management a challenge to most commercial entrepreneurs?

\section{B. Willingness to Pay}

From the findings, it was established that most of the commercial enterprises were willing to pay for solid waste collection and transportation. This finding concurred with [25]. However, it was contrary to [23], [26], [27] that in most African towns and cities commercial enterprises are not willing to pay for solid waste management. In a normal setting of an urban environment, commercial enterprises pay levies to municipal councils. Part of these levies is meant to cover solid waste collection, transportation, and safe disposal. Essentially, the levies charged part of it is used to address solid waste management. The study found that approximately a third of the commercial enterprises made daily payments for solid waste collection; however, $61.9 \%$ were not paying for the transportation of the solid wastes. These are some of the factors that contributed towards increased solid waste challenges in Kakamega town. It could be seen from [13] study conducted in Kisumu City. which reported that most waste generators were unable to pay for solid waste management. Therefore, willingness to pay for solid waste collection, transportation and safe disposal is an area that needs to be emphasised among the commercial enterprises in order to holistically keep Kakamega town clean and manage the illegal dumping sites.

\section{Incentives \\ 1) Escape Routes}

The incentive provision by the authorities to commercial enterprises promotes the involvement of commercial enterprises in solid waste management practices. It could be noted that municipalities in Kenya face challenges accessing transfer points due to the poor planning of most towns. Changing the culture and perception of solid waste management practices by commercial enterprises in Kakamega town is the main predictor of improved solid waste management. It was stated by [28] that less than half of solid waste generated in most urban centres in Africa is collected which concurs with this finding. Therefore, illegal transfer points/dumpsites emerge conveniently accessible to commercial enterprises. This contributes to increasing cases of illegal, unregulated mixed municipal solid waste menace in the urban centres. In reference to [29], the location of a dumpsite should be determined by the infrastructures for solid waste management and the residential establishments to avoid destructive aesthetics - visual and air pollution. To promote solid waste management practices in Kakamega 
town, it is prudent to make transfer points/dumpsites accessible to commercial enterprises that are properly managed by the municipal council [30]. The existence of illegal dumping sites in urban centres is a norm in the global south [31]. Besides, inaccessibility to dumpsites is a precursor of poor network systems as a function of the municipal council [32]. Accessibility to sufficient resources such as waste vehicles and accessible routes to the disposal sites have a direct relationship with efficient solid waste management.

\section{2) Importance of low solid waste charges}

However, this is not the current practice in Kakamega town; commercial enterprises are not motivated to embrace solid waste management. This finding concurred with [33] that commercial enterprises lacked incentives. It is therefore important to try extending incentives - motivation -to commercial enterprises as a means of promoting solid waste management practices in Kakamega town as also seconded by the results from the focused group discussion. Solid waste management is resource-based such as financial abilities to procure collection bins, pay for collection and transportation makes it an expensive affair. Thus, the cost of implementation of solid waste management discourages commercial enterprises from participating as acknowledged by [15].

\section{CONCLUSION}

From the correlation model summary that produced $r=0.882$ for both awareness levels by the respondents on transportation and safe disposal, while $r=0.375$ on collection; meant that the respondents who were aware of their waste transportation were also aware of its disposal and those who only participated in the solid waste collection were slightly aware of how it was transported and where it was disposed thus influencing illegal littering and dumping in Kakamega Central Business District. Also, 67.6\% of the respondents were willing to pay a mean amount of Kes. 92 and 71 for daily solid waste collection and transportation respectively. The amount paid was insufficient to cater for the solid waste management practices within the Kakamega CBD thus resulting in a high accumulation of the mixed waste in its environment. The proximity to the transfer points was a very important and extremely important incentive that strongly predicts the frequency of solid waste management practices $(\mathrm{r}=0.720)$. Meaning distance to the transfer point and disposal site influenced the frequency of solid waste management practices by the commercial enterprises.

\section{RECOMMENDATION}

Enhancing the collection of solid waste among the commercial enterprises other than depending on the municipal council alone could improve the management of solid waste in the study area. It will also help in reducing the amount of solid waste littering and causing harm to the environment.

\section{ACKNOWLEDGEMENT}

My foremost gratitude is to almighty God for giving me the ability and passion to carry out this study. Secondly, I thank all my supervisors Prof. Boniface Oluoch Oindo and Dr Albert Elim Long'ora for their inspirational guidance and encouragement for the success of this study. Thirdly, I appreciate the efforts and support from my entire family members especially my Mother Ms Edah Awinja, and my Wife Catherine Mabinda for their moral, financial and spiritual support.

\section{REFERENCES}

[1] World Bank. Solid Waste Management [Internet]. World Bank. 2018 [cited 20192 Feb 23]. Available from: http://www.worldbank.org/en/topic/urbandevelopment/brief/solidwaste-management.

[2] Laor P, Suma Y, Keawdounglek V, Hongtong A, Apidechkul T, Pasukphun N. Knowledge, attitude and practice of municipal solid waste management among highland residents in Northern Thailand. Journal of Health Research. 2018 Mar 12.

[3] Vitenko T, Marynenko N, Kramar I. European Experience in Waste Management. Environmental Sciences Proceedings. 2021;9(1):17.

[4] Tadesse TB, Tefera SA, Kidane MT. Comprehensive Solid Waste Dumpsite Selection in Arid Cities of Northeastern Ethiopia: A SpatialMCDA Approach. Journal of the Air \& Waste Management Association. 2021 Jan 23.

[5] Mutungwe E, Tsvere M, Munikwa S, Dondo B, Pedzisai C. A study of the level of awareness and practices of solid waste management in Chinhoyi, Urban, Zimbabwe. International Journal of Advanced Research in Management and Social Sciences. 2014;3(9):71-9.

[6] Kinobe JR, Bosona T, Gebresenbet G, Niwagaba CB, Vinnerås B. Optimization of waste collection and disposal in Kampala city. Habitat International. 2015 Oct 1;49:126-37.

[7] Boateng KS, Agyei-Baffour P, Boateng D, Rockson GN, Mensah KA Edusei AK. Household willingness-to-pay for improved solid waste management services in four major metropolitan cities in Ghana. Journal of environmental and public health. 2019 Jan 2;2019.

[8] Mulat S, Worku W, Minyihun A. Willingness to pay for improved solid waste management and associated factors among households in Injibara town, Northwest Ethiopia. BMC research notes. 2019 Dec;12(1):1-6.

[9] Serge Kubanza N, Simatele MD. Sustainable solid waste management in developing countries: a study of institutional strengthening for solid waste management in Johannesburg, South Africa. Journal of Environmental Planning and Management. 2020 Jan 28;63(2):175-88.

[10] Shivoga WA. Demand for, awareness on and constraints to proper solid waste management in Njoro Division, Nakuru, Kenya. 2016.

[11] ODERA JJ.An assessment of socio-economic factors influencing electronic waste management in Kisumu Central business district, Kisumu city, Kenya (Doctoral dissertation, Maseno University). 2016.

[12] Atieno JV. An analysis of socio-economic and demographic determinants for estimating solid waste generation in households in estates in Kisumu city, Kenya (Doctoral dissertation, Maseno University). 2018.

[13] Sibanda LK, Obange N, Awuor FO. Challenges of solid waste management in Kisumu, Kenya. InUrban Forum 2017 Dec (Vol. 28, No. 4, pp. 387-402). Springer Netherlands.

[14] Nyayiemi SK. Determinants of effective solid waste management in Kakamega Municipality, Kenya (Doctoral dissertation, University of Nairobi, Kenya). 2012.

[15] Malenya KM. Determinants of effective solid waste management in Kakamega county. Strategic Journal of Business \& Change Management. 2015;2(2).

[16] Republic of Kenya. National Sustainable Waste Management Policy. Ministry of Environment and Forestry. Sessional Paper No. X of 2018 on National Sustainable Waste Management Policy. 2019.

[17] Kanda E, Cherono K. Evaluation of Solid Waste Management Practices in Kakamega Municipality, Kakamega County.

[18] Kakamega County Integrated Development Plan (2018 - 2022). 2018

[19] Kenya National Bureau of Statistics. 2019 Kenya Population and Housing Census Results. 2019 November 4. https://www.knbs.or.ke/2019-kenya-population-and-housing-censusresults/ Retrieved on $8^{\text {th }}$ January 2022. 
[20] Yukalang N, Clarke B, Ross K. Barriers to effective municipal solid waste management in a rapidly urbanizing area in Thailand. International journal of environmental research and public health. 2017 Sep;14(9):1013.

[21] Damtew YT, Desta BN. Micro and small enterprises in solid waste management: Experience of selected cities and towns in Ethiopia: A review. Pollution. 2015 Oct 1;1(4):461-27.

[22] Olukanni DO, Adeleke JO, Aremu DD. A review of local factors affecting solid waste collection in Nigeria. 2016.

[23] Kirama A, Mayo AW. Challenges and prospects of private sector participation in solid waste management in Dar es Salaam City, Tanzania. Habitat International. 2016 Apr 1;53:195-205.

[24] Oyake-Ombis L, van Vliet BJ, Mol AP. Managing plastic waste in East Africa: Niche innovations in plastic production and solid waste. Habitat International. 2015 Aug 1;48:188-97.

[25] Song Q, Wang Z, Li J. Residents' attitudes and willingness to pay for solid waste management in Macau. Procedia environmental sciences. 2016 Jan 1;31:635-43.

[26] Kaza S, Yao L. At a Glance: A Global Picture of Solid Waste Management. 2018.

[27] Otumawu-Apreku K. Solid Waste Management: A Socio-Economic Perspective of Urban and Peri-Urban Communities in Honiara. International Journal of Environmental Sciences \& Natural Resources. 2020;25(4): 180-92.

[28] Addaney M, Oppong RA. Critical issues of municipal solid waste management in Ghana. JENRM. 2015;2(1):30-6.

[29] Srangsriwong A, Olapiriyakul S, Yenradee P. Factors influencing public perception and impact distance of a municipal solid waste dumpsite in Thailand. Asia-Pacific Journal of Science and Technology. 2019;24(1).

[30] United States Environment Protection Agency. Best Practices for Solid Waste Management: A Guide for Decision-Makers in Developing Countries. The United States Environmental Protection Agency. 2020 https://www.epa.gov/sites/production/files/2020-

10/documents/master_swmg_10-20-20_0.pdf Retrieved on 14th May 2021.

[31] Naibbi AI, Umar UM. An appraisal of spatial distribution of solid waste disposal sites in Kano metropolis, Nigeria. Journal of Geoscience and Environment Protection. 2017 Nov 2;5(11):24-36.

[32] Douti NB, Abanyie SK, Ampofo S. Solid waste management challenges in urban areas of Ghana: A case study of Bawku Municipality. 2017.

[33] Debrah JK, Vidal DG, Dinis MA. Raising awareness on solid waste management through formal education for sustainability: A developing countries evidence review. Recycling. 2021 Mar;6(1):6.

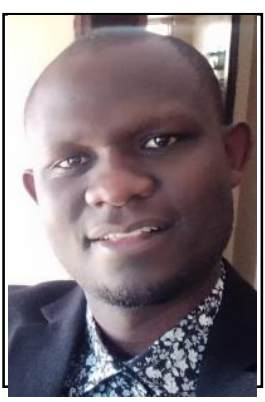

Robert Mbatsi Kuya is a Masters Degree student of Maseno University. Professionnaly, Robert is an Environmental Conslutant registered under the National Environment Management Authority in Kenya. He is also a member of Environment Institute of Kenya. 